N. Mazaraki, orcid.org/0000-0002-1729-7846, A. Gerasymenko, orcid.org/0000-0003-0313-6942
Kyiv National University of Trade and Economics, Kyiv, Ukraine, e-mail: n.mazaraki@knute.edu.ua

\title{
DEFINING THE STANDARD OF MARKET ANALYSIS IN SECTORS OF STRONG SOE PRESENCE
}

Purpose. Defining of the criteria that determine a choice of the standard of market analysis in the sectors with strong presence of state-owned enterprises (SOEs).

Methodology. The methodological basis of the study is a comparative analysis of the principles of classifying SOEs and SOEs' activities in different countries and the results of their analysis under neoclassical and institutional standards that have resulted in the set of criteria which determine the prerequisites of applying certain standard.

Findings. The paper grounds the impermissibility of the common use of the neoclassical standard of market analysis in sectors of strong SOE presence. It specifies the set of criteria that determine when each of the standards (neoclassical and institutional ones) should be applied.

Originality. The criteria that determine a choice of the standard of market analysis in the sectors with strong SOE presence are defined. They include a type of the economic system, a type of the SOE, its functional dependency on the state agency, structure of the state control over its property.

Practical value. The results of the research, being implemented in the activity of a competition agency, allow providing more accurate market analysis of the grounds and a practice of competition within the markets, as well as within the entire economy.

Keywords: state-owned enterprise (SOE), control, market analysis, standard of market analysis, competition

Introduction. Industrial Economics and Competition Law, working together over more than a century, have developed some approaches to market analysis and institutionalized them up to the standards. Among them are: claim to determine product, geographical and temporal boundaries of a market as a premise of its next investigation; predetermination of market actors' behaviour with the market structure, provided by SCPparadigm; considering the group of enterprises, which are interconnected by control, as a single market actor. To explain the meaning of the term "control" let us put the excerpt of para. 1 of Ukrainian Law "On the protection of economic competition", which determines a control as "a decisive impact on economic activities of an economic entity or its part that is exerted by one or more than one related legal and (or) natural persons directly or through other persons, in particular by: part;

- the right to own or use all the assets or their considerable

- the right ensuring a decisive impact on the formation, voting results, and decisions of managing bodies of the economic entity;

- the conclusion of such agreements and contracts that make it possible to set conditions for economic activities, to give binding instructions or to perform functions of the managing body of the economic entity;

- the occupation of the position of the head, a deputy head of the supervisory board, the board of directors or of other supervisory or executive board of the economic entity by such a person that occupies one or several of the mentioned positions at other economic entities;

- the occupation of more than half of the positions of members of the supervisory board, the board of directors, other supervisory or executive boards of the economic entity by such persons that occupy one or several of the mentioned positions at another economic entity" [1].

All the enterprises interconnected by control are considered a single economic entity in terms of market analysis. Such an approach dominates in theoretical studies and competition laws of the developed countries. In recent decades, it has become prominent in the developing countries as well [2]. The former, who have been developing their economies on the principles of libertarianism for decades, disseminate this approach onto the latter, who meet a new challenge - divergent

(C) Mazaraki N., Gerasymenko A., 2020 network of state-owned enterprises (SOEs), which compete one each other, on the one hand, and are interconnected by control, on the other hand.

Hence, the question came up: should the well-established institutional standard of market analysis be applied in the sectors of strong SOE presence? Are the roles of state and private shareholder commensurable in terms of ruling a business? Is an owner control of a state over the activity of SOEs sufficient for making the competitive strategies of the latter consistent? Is it correct to analyse all the SOEs within a market as a single market actor or they must be considered as different economic entities? There are no answers to these questions.

In centrally planned economy, where the enterprises have not commercial independence and have to work under the government-set plans of output, to sell their products at the fixed prices, it is believed that all the SOEs have to be considered as a single economic entity in terms of market analysis. In such a case no enterprise develops an independent market strategy, but keeps the role that is assigned to it by the state. It cannot be found an independent competitor in the market. In the market economy or mixed one with dispersed ownership structure (for example, the American one), where the state is one of many SOEs' shareholders and the functions of possession and governance of state property are separated (so called neoclassical model), there is a matter of separate consideration of every SOE. The impact of the state on its business practice is restricted, being manifested only in intermittent acts of assigning the management of SOE, approval of its reports, etc.

The dominance of market economy principles in the global economy, as well as in the economies of the majority of certain countries, says for the validity of the latter approach. The same findings arise from the research on corporate management studies in general and management of SOEs in particular. Many of them put an emphasis on the restricted role of the state and the citizens as ultimate owners of state property in the management of SOE.

Literature review. Developing A. Berle and G. Means, M. Jensen and W. Meckling, and E. Fama research on freerider dilemma between agents and principals, G. Charreaux raises a question of 'under ownerless' of the shareholding of SOEs [3]. If the agency problem is burning for the private business, where corporate management is a first-hand agent of the shareholders, it will be even more critical for the public one, where there is a long chain of agents (parliamentarians - ex- 
ecutive officers - SOE management) between the ultimate owner (a citizen) and their property (the SOE). It is another argument for the separate consideration of SOEs for purposes of market analysis. The similar ideas are presented by G. Lallemand-Kirche, C. Tixier, H. Piffaut [4], V. Šmejkal [5], P. Kowalski, D. Rabaioli and S. Vallejo [6], M. McLaughlin [7], and others. However, these arguments are not enough for any-time applying of the separate consideration of SOEs under market analysis, especially in the light of the problem of discrepancy between theoretical models of state property management and the real practice of it. The transparent relation between the state and business is an ideal neoclassical model that is uncommon. In very deed, there are many SOEs in different countries that work closely with the state authorities, falling into the line with their strategic decisions, practicing the tactics of their competitive behaviour in accordance to it. We can speak here on the Chinese or Russian practice, about the practice of such European countries as Norway or Finland, where the traditions of state business are deep.

Purpose. The mentioned above makes it obvious that there is no chance to apply the single standard of market analysis to all the cases in the sectors of strong SOE presence. It determines the aim of this paper as defining of the criteria that determine a choice of the standard of market analysis in the sectors with strong SOE presence.

Methods. To find out how to consider SOEs in market analysis, the authors research the principles of their classification and the business practice of SOEs in different countries. They draw conclusions on the applying of different standard of SOE market analysis in case of their different types and the difference in their relationship with state authorities. The effect of the adopted standard on the results of market analysis has been illustrated by evidence from the Kyiv market of passenger transport services. They also study some structural and institutional factors that influence the choice of the standard of SOE market analysis.

Results. Despite the extensive privatization programs implemented in the 1980s and 1990s SOEs are still widespread in many countries. Recent years their share in assets' value of the 2000 largest companies even has tended to rise, first of all because of the strong expansion of Chinese SOEs (Fig. 1). That means that notwithstanding the calls for liberalization of the economies there are many reasons for national governments to keep state control over business through the state ownership of commercial enterprises. Among them are:

- control of strategic resources;

- guarantees of better distribution of wealth and power within society;

- involvement of SOEs into countercyclical regulation, first of all in the sector of employment;

- providing public goods such as the postal service, health care, etc.;

- minimization of negative externalities in alcohol production, gaming, etc.;

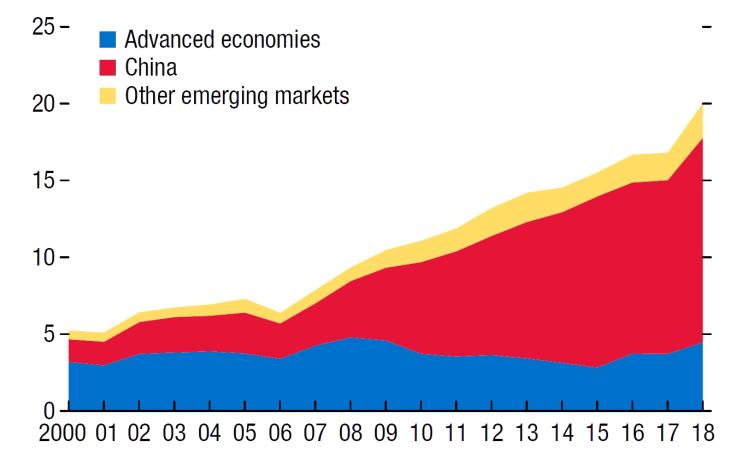

Fig. 1. Share of Nonfinancial SOEs among the 2000 Largest Firms, \% [9]
- concentration of economic resources for global competition, etc. [8].

The reasons of SOEs existence are rather different. Some of them need the close and systematic cooperation with state authorities and exploitation of the coercive power of the latter. The others may be implemented by private or mixed ownership enterprises. Usually, different groups of reasons create different groups of SOEs.

The analysis of institutional framework and practice of public sector functioning in different countries let us segregate two main types of SOEs, while SOE classifications in some of the countries may be much wider and segregate up to seven types of government-owned entities. The first type comprises SOEs that work in business environment head-to-head with private enterprises and means narrow state impact on them. Usually the latter is restricted by shareholder rights, such as:

- assigning the members of the SOE's board of management within the state quota of votes or determination the rules and procedures of the process of chief management recruiting;

- approving the annual report on the results of SOE's business practice;

- getting the dividends, and so on.

The state has no business to operational activity of a SOE. It must not govern the competitive behaviour of a SOE. Exactly such SOEs have a chance to be considered as an independent market participants (in terms of the neoclassical tradition in economics), if there are no other arguments for their integration into mutual economic entity.

The second type of SOEs comprises the enterprises that are heavily dependent on the state agencies up to be integrated into them. Such SOEs might fail to have a committed budget and operate under the state agency budget. Being public consumption oriented, they may be unprofitable. They are operated under no private, but public law. One can call them a hybrid of a state agency and a market oriented enterprise. In market analysis such SOEs must not be considered as independent market participants, because of their institutional, financial and other kinds of dependence on a parent state agency that exerts a strong influence over the competitive strategy of SOEs.

This classification is a simulated one. It varies from one country to another, where the state agencies and the SOEs may have a greater or smaller complex of rights and freedoms as a background of the applying of the neoclassical or the institutional standard of SOE market analysis.

German Law allocates two types of SOEs:

- undertakings which are entirely or partly in public ownership;

- undertakings which are managed or operated by public authorities [8]), that fully conform to the classification above.

There is the same classification in India. Here the SOEs are divided into two groups: departmental enterprises and non-departmental enterprises. Departmental enterprises are part of government financial system with funding coming from the general budget but under separate accounts of income and expenditure. Highways, construction of houses, educational and health services, postal services all constitute departmental enterprise [8]. May such enterprises be considered as separate market participants that are independent of the state agency? On no account. They are under the strict financial control of the agency because of government funding. The agency supervises their day-by-day activity to be sure in targeted use of financial resources. In such a case the agency and all its associated SOEs must be considered as a single economic entity in terms of market analysis.

Non-departmental enterprises are legally separated from the government and maintain a separate set of accounts. They operate under private law [8]. Such SOEs may be considered separately from the state agency and its other ancillaries in the market analysis, if there are no other factors of their dependency. 
The Korean classification of SOEs is similar to the ones mentioned above. According to the Korean Act on the Management of Public Institutions there are three types of public institutions that are allocated in the two-level hierarchical scheme of classification (Fig. 2). At the first level there are two types of public institutions: public corporations and quasi-governmental institutions. Public corporations refer to firms, whose self-generating revenue takes up a half or more of the total revenue, and they are again classified into market-type public corporations whose asset size reaches 2 trillion won or more and self-generating revenue accounts for $85 \%$ of the total revenue and quasimarket-type public corporations that are not market-type ones. Quasi-governmental institutions refer to public institutions other than public corporations. Quasi-governmental institutions generally conduct services commissioned by the government rather than run business in the market [10].

The only one of three types of public institutions from Fig. 2 bears the marks of an independent market participant market-based public corporations. The others have not them, being different organisational forms of state business activity. They must be considered as a single economic entity in terms of market analysis, keeping with the tradition of the institutional theory.

An approach similar in spirit can be found in Swiss Law, which, however, is classified within a one-level classification scheme . It regards enterprises as public in different cases:

- if they are constituted as public-legal forms being autonomous or non-autonomous institutions incorporated under public law;

- federal or cantonal offices are considered as public, if they render commercial services in addition to the execution of their sovereign tasks;

- if they are subject to private law and totally or partially in public ownership [8].

As in the previous case two of the three types of SOEs involve too close relationship with parent state agencies to be considered under the neoclassical standard of SOE market analysis. The third one implies the larger discretion in sphere of executive decision-making that gives the SOEs a chance to become a separate target of market analysis. The final decision depends on the specific framework of interaction between the SOE and the agency that is responsible for the control and the strategic governance of this SOE. That means that the matter of choice of the standard of SOE market analysis is the extent of state control over the SOE.

So far, we have spoken about the SOEs that operate nationwide, while the municipal enterprises also need the research. In many countries they have a special status that implies the specific kind of economic relations between the municipal enterprise and the local government. Among such countries are Norway and Finland. Let us look at the Finnish relevant practice.

The Finnish traditions of state business are deep and the state control over SOEs is rather strict, especially at the municipal level. Municipal entities are usually established in order to produce welfare services (health care, social services, education, infrastructure-related technical services, and cultural

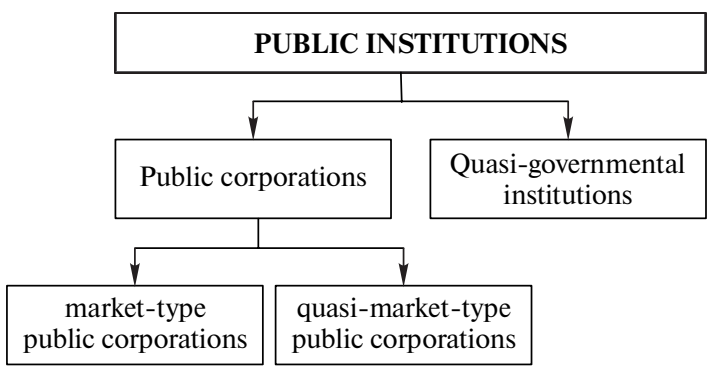

Fig. 2. Classification of the public institution in the Republic of Korea [10] services). There are four types of them by the organizational form and the extent of state control over them (agency, net budgeted cost or profit unit, enterprise, and company), but all of them are dependent on local government [11], because of their cross-institutional functionality. Business activity of a municipal supplier of welfare services and regulatory activity of a local government are tightly intertwined: the first one produces some public goods or welfare services for the needs of community, while the latter, often being an exclusive customer of the first, determines all the specifications of the delivery contracts, as well as the institutional environment of business activity of certain municipal entity. They cannot be considered as separate economic entities, asking for the use of the institutional standard of SOE market analysis. It is true not only for Finnish municipal enterprises, but for many other ones that let us extend the conclusion on the standard of SOE market analysis to other jurisdictions - even those ones that have no reputation for acceptance of state business at large.

The European Commission takes a complex approach to define the market position of an undertaking within the scope of Article 102 of the TFEU. G. Lallemand-Kirche and others have summarized types of evidence used be the European Commission to demonstrate whether an SOE can be considered as independent and which other SOEs can be part of the same single economic unit: "the involvement of the State in decisions concerning commercial activities, or its ability to influence such activities; the legal ability of the State to take decisions for the SOE, the State's right to give instructions to the SOE, its powers of supervision, the possibility of approving the amendment of the SOE's by-laws, its power of guaranteeing liabilities of the SOE, its ability of appointing board members so as to have the majority of voting rights, and so on; the existence of formal or informal relations between SOEs, in particular through interlocking directorships; the past relationship between two SOEs controlled by the same State entity. The question in such cases was whether the two SOEs' operative matters were run independently, by separate management, and whether the State only exercised its ownership control in questions relating to the shareholding of the State" [4].

The US experience of state business practice is interesting, considering that its economy is known as some kind of gold standard of market economy. On the one hand, American legislation does not contain a specific term to denote an SOE. The publicly owned companies have to meet severe requirement of clear determination of their relationship to the government in corporate charter or statutory authorization. The Law prohibits any legal exemptions and/or privileges, for the benefit of other economic actors with which it interacts and asks for clear separation between the state's ownership function and other state functions that influence market conditions, particularly with regard to market regulation. On the other hand, some SOEs are tightly intertwined with state agencies. They are called 'federal government corporations' or 'quasi government entities', comprising government-sponsored enterprises and federally funded research and development centres. These federal government corporations established by the Congress to provide the economy with public goods operating at break-even point. Among them are: Export-Import Bank, Federal Deposit Insurance Corporation, Commodity Credit Corporation, Federal Crop Insurance Corporation, Amtrak, Federal Financing Bank, U.S. Postal Service, Federal Prison Industries and others. Some of them are located within executive departments with employees who are actually employees of the parent government agency [8]. The applying of the neoclassical standard of market analysis to these SOEs would be incorrect. Their market behaviour must be researched in the context of their dependence on parent state agencies.

Let us also turn our attention to Spanish and Romanian experience of SOEs' business practice. Its general framework in these countries is similar to the German and Indian ones that were discussed above. Spanish and Romanian SOEs are 
divided into two groups. One of them comprises public enterprises that are under dominant impact of a parent state agency; the other comprises commercial companies, which are marked by poor governance competences of a parent state agency that are restricted by the set of shareholder rights. Expanding the previous logic of the study to these cases may bring the conclusion about the necessity of applying the neoclassical standard of SOE market analysis to the latter group of SOEs. But this would be wrong, because of the fact that the state control over all the SOEs in these countries is concentrated in the hands of the single state holding company - Autoritatea pentru Administrarea Activelor Statului - Authority for State Assets Management (AAAS) in Romania and Sociedad Española de Participaciones Industriales - Spanish Society of Industrial Stakes (so called SEPI Group) in Spain. They are the strategic instruments for implementing the governments' policy for the state entrepreneurial sector. This fact in addition to the high concentration of state ownership makes an argument for the applying of the institutional standard of SOE market analysis.

So, the determination of the standard of SOE market analysis in the markets with strong state presence depends not only on the type of the SOE, but also on the way of arrangement of state control over their business practice: structural and institutional. There is no urgent need in creating a certain holding company or agency to concentrate state control over the SOEs. Sometimes it is enough to adopt some laws or other official acts that establish a non-transparent, but concentrated and rigid SOEs' governance model in the country, sector or community.

There are two types of SOEs in Ukraine that suit to the above simulated classification: commercial and non-commercial ones. Non-commercial SOEs are under strict control of the parent state agencies, which means the right of the latters to determine the business practice of such SOEs. There is a joint financial responsibility of the agency and non-commercial SOEs in Ukraine. In such a case we definitely have to apply the institutional standard of SOE market analysis, considering all the related enterprises and the governing agency as a single economic entity.

In the case of state commercial enterprises the choice is not so evident. On the one hand, the Ukrainian Law 'On management of state ownership' implies an independence of state commercial enterprises on the state agencies. There is a clear list of the state agencies' competences in the sphere of state property management. Among them are:

- making a decision for establishment, restructuring or dissolution of a state commercial enterprise;

- approving the chart of a state commercial enterprise;

- appointment of the managers to key positions of a state commercial enterprise;

- approving of strategic plans of the development of a state commercial enterprise;

- approving of annual financial and investment plans, as well as mid-term investment plans (3-5 years) of a state commercial enterprise;

- monitoring of financial activity of a state commercial enterprise, first of all - the indicators of financial plan fulfilment [12].
This Law forbids the intervention of the agency into the business operations of state commercial enterprises.

On the other hand, even the competence to approve the strategic and tactical financial and investment plans is a factor that provides a decisive influence of a parent state agency on competitive behaviour of a state commercial enterprise. Such an enterprise is not independent enough to be considered as a separate economic entity in terms of market analysis. The same conclusion must be made because of the obligation of all state commercial enterprises to accept and accomplish all the government orders that is fixed by the Commercial Code of Ukraine. These orders must be taking into account while drawing up the production program of state commercial enterprise, evaluating the perspectives of its economic and social development, and choosing the contractors [13].

The situation is even more difficult at the municipal level. According to the Ukrainian Law, the municipal commercial enterprises operate on the principle of economic independence. However, the fact is that their business activities are strictly determined by decisions of parent municipalities.

Let us consider the activities of two municipal commercial enterprises that operate in the local Kyiv market of passenger transport services: MC "Kyivskyi metropoliten" and MC "Kyivpastrans". Both enterprises are under the authority of the Department of Transport Infrastructure of executive office of Kyiv City Council (Kyiv City State Administration). Apart from basic competences of top management appointment and general owner control of these companies, Kyiv City State Administration determines the volumes and the structure of their output, fixes prices of passenger transport services, approves the value of investment projects and finances them from the local budget, and subsidizes these two enterprises in order to improve their financial health. According to the financial plan of MC "Kyivskyi metropoliten" for 2019, 26\% of its revenue was state financing. For MC "Kyivpastrans" this figure is even higher $40 \%[14,15]$. These enterprises raise credit resources (i.a. EBRD loans) on the security of Kyiv City State Administration. For instance, Kyiv City State Administration guarantee for EBRD loan to MC "Kyivpastrans" amounted to more than 300K UAH in 2019 and almost 700K UAH in 2018 [16]. Such a policy of Kyiv City State Administration draws the line between these two municipal commercial enterprises and other market participants. The oneness of the approaches to governance of MC "Kyivskyi metropoliten" and MC "Kyivpastrans" by this municipal agency precludes the researcher from the applying the neoclassical standard of SOE market analysis in this case.

Fig. 3 illustrates the structure of local Kyiv market of passenger transport services under both standards of SOE market analysis that let us size up the error range of the wrong choice of the standard from the standpoint of the simplest structural approach. The applying of the neoclassical standard gives us the hard core oligopoly market that does not preclude the competition between oligopolists. The applying of the institutional one gives us the market with structural backgrounds of unilateral dominance, where market equilibrium is determined by the Department of Transport Infrastructure of Kyiv City State
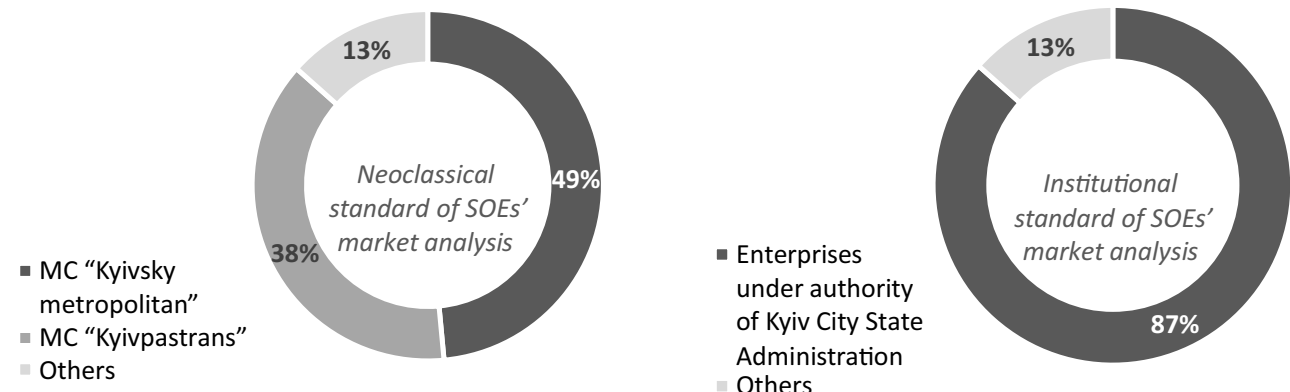

Fig. 3. The structure of local Kyiv market of passenger transport services [17, 18] 
Administration. There are two different market models that mean the different conduct of market participants. So, the applying of the wrong standard of SOE market analysis creates an incorrect picture of market configuration that leads to the incorrect managerial solution or inconsistent regulatory actions.

The fact that we are talking about the market power of public owner represented by Kyiv City State Administration rather than private owner does not reduce the level of the threat. It only conceals it. Neoclassical economics argues that state is a 'night watchman' that serves to protect public interests and to regulate market failures. The institutional economics is not so naive. It is aware of the variety of risks caused by the state monopoly, especially if there is:

- lack of effective institutes of protection and development of competition;

- entwinement of functions of state agencies and SOE management bodies;

- no effective public control over state authorities, which is particularly true for such countries as Ukraine. This also exacerbates the problem of correct choice of the standard of SOE market analysis, calling for closer look into the existent system of economic relations between the parent state agency and the associated SOEs.

Conclusions. The full transposing of approaches to market analysis from the private sector to the sector with strong state presence is incorrect. The reason involves the effects caused by the state property rights and the relevant administration functions of the state agencies. If there is only one SOE in the market or in the group of adjacent markets, these effects may remain covert; but in the case of two or more SOEs there is an urgent need for correct choice of the standard of their market analysis.

The neoclassical standard of SOE market analysis must be applied when the activities of the SOEs are really independent, and the governance functions of the parent state agency are restricted, excluding the possibility of state decisive influence over the competitive strategies of the SOEs. The institutional standard of SOE market analysis must be applied when the activity of the SOEs is under strict control and decisive influence of the parent state agency that makes the managerial decisions with the purpose of maximization of the total benefits of the whole scope of the associated SOEs through the coordination of their competitive strategies.

Since the real target function of the public management in different sectors/markets is unknown, the researcher needs some criteria for choice of the standard of SOE market analysis. Summarizing the results of the current research, let us stand out the following list of such criteria:

- the type of the economic system and the role of the state in the structure of its economic mechanism;

- the type of the SOE and the degree of its statutory dependency on the parent state agency;

- the functional dependency of SOEs' activity on the conduct of the state agency;

- the structure of the state control over its property.

The use of these criteria allows making the choice of the standard of SOE market analysis more tenable and its results more correct. Promotion of the criteria-based choice of the relevant standard of SOE market analysis into the national procedures of market analysis may be a real step to implement the principle of competitive neutrality that is declared by the majority of competition authorities in the world, but hardly anywhere really implemented.

\section{References.}

1. VRU, Verkhovna Rada of Ukraine (2001). Ukrainian Law "On the protection of economic competition" No. 2210-III dated 11 Jan. 2001. Retrieved from http://zakon3.rada.gov.ua/laws/ show/2210-14.

2. EC, European Commission Council Regulation (2004). On the Control of Concentrations between Undertakings No. 139/2004 dated 20 Jan. 2004 Retrieved from http://ec.europa.eu/competition/mergers/legislation/regulations.html.

3. Bréchet, J.-P., Charreaux, G., Desreumaux, A., \& Montmorilon, B. (2015). L'entreprise, son projet, sa gouvernance: éléments d>une vision partenariale. Economies et Sociétés. Série Economie de l'Entreprise, 23(1), 33-65. https://doi. org/10.13140/RG.2.1.2614.5766.

4. Lallemand-Kirche, G., Tixier, C., \& Piffaut, H. (2017). The Treatment of State-owned Enterprises in EU Competition Law: New Developments and Future Challenges, Journal of European Competition Law \& Practice, 8(5), 295-308, https:// doi.org/10.1093/jeclap/lpx016.

5. Šmejkal, V. (2019). Chinese state-owned enterprises and the concept of undertaking under EU competition law. Journal for International and European Law, Economics and Market Integrations, 6(2), 31-51. https://doi.org/10.22598/iele.2019.6.2.2. 6. Kowalski, P., Rabaioli, D., \& Vallejo, S. (2017). International Technology Transfer measures in an interconnected world: Lessons and policy implications. OECD Trade Policy Papers, 206, OECD Publishing, Paris. https://doi.org/10.1787/ada51ec0-en. 7. McLaughlin, M. (2019). Defining a State-Owned Enterprise in International Investment Agreements. Foreign Investment Law Journal, 34(3), 595-625. https://doi.org/10.1093/ icsidreview/siz011.

8. OECD (2010). State Owned Enterprises and the Principle of Competitive Neutrality: OECD Working Paper DAF/ COMP(2009) 37. Retrieved from https://www.oecd.org/daf/ competition/46734249.pdf.

9. IMF, International Monetary Fund (2020). Fiscal Monitor: Policies to Support People During the Covid-19 Pandemic. Retrieved from https://www.imf.org/en/Publications/FM/Issues/2020/04/06/fiscal-monitor-april-2020.

10. NARK. The National Assembly of the Republic of Korea (2016). Act on the Management of Public Institutions Act No. 14461, 27 Dec. 2016. Retrieved from https://elaw.klri.re.kr/ eng service/lawView.do?hseq=41210\&lang=ENG.

11. Kowalski, P. (2019). State-owned Enterprises and the Trade Wars. Norwegian Institute of International Affairs. Policy Brief, 6. Retrieved from https://www.nupi.no/en/Publications/CRIStin-Pub/State-owned-Enterprises-and-theTrade-Wars.

12. VRU, Verkhovna Rada of Ukraine (2006). Ukrainian Law "On management of state-owned entities" No.185-V dated 21. Sep. 2006. Retrieved from http://zakon0.rada.gov.ua/laws/ show/185-16.

13. VRU, Verkhovna Rada of Ukraine (2003). Commercial Code of Ukraine No.436-IV dated 16 Jan. 2003 Retrieved from http://zakon2.rada.gov.ua/laws/show/436-15/page3.

14. KM, Kyivskyi Metropoliten (2019). Financial plan of $M C$ “Kyivskyi Metropoliten” for 2019. E-portal Kyivaudit. Retrieved from https://kyivaudit.gov.ua/pdf/fp/01_01_19/03328913_5 NFP.pdf

15. Kyivpastrans (2019a). Financial plan of MC "Kyivpastrans" for 2019. E-portal Kyivaudit. Retrieved from https://kyivaudit.gov.ua/pdf/fp/01_01_19/31725604_5 NFP.pdf.

16. Kyivpastrans (2020). Marks on financial statement of $M C$ "Kyivpastrans" in 2019. Retrieved from https://kpt.kyiv.ua/ uploads/u/1/WaUsDsS0jjxHb_cgBCINTRgEi_3c2g_L.pdf. 17. KSSS, Kyiv State Statistic Service (2019). Passenger traffic in 2018. Retrieved from http://kiev.ukrstat.gov.ua/p. php3? $=1016 \&$ lang $=1$.

18. Kyivpastrans (2019b). Report on management of $M C$ " $K y$ ivpastrans" in 2018. Retrieved from https://kpt.kyiv.ua/ uploads/u/1/xa7z0tCLJog8faMeZk3VxyliodbE7Q2B.pdf.

\section{Визначення стандарту ринкового аналізу в галузях зі значною часткою державних підприємств}

\section{Н.А. Мазаракі, А. Г. Герасименко}


Київський національний торговельно-економічний університет, м. Київ, Україна, e-mail: n.mazaraki@knute.edu.ua

Мета. Визначення критеріїв, що детермінуватимуть вибір стандарту ринкового аналізу в галузях зі значною часткою державних підприємств

Методика. Теоретико-методичним підгрунтям дослідження $є$ компаративний аналіз принципів класифікації й досвіду функціонування підприємств державної форми власності у різних країнах світу, результатів їх ринкового аналізу в межах неокласичного та інституційного стандартів, на підставі яких виокремлено набір критеріїв, що детермінують передумови застосування кожного зі стандартів.

Результати. У роботі обгрунтована неприпустимість повсюдного застосування неокласичного підходу до ринкового аналізу в галузях зі значною часткою державних підприємств. Детерміновано набір критеріїв, що визначають, за яких обставин слід використовувати неокласичний, а за яких - інституційний стандарт ринкового аналізу.

Наукова новизна. Визначені критерії, що детермінують вибір стандарту ринкового аналізу в галузях зі значною часткою державних підприємств, в числі яких: тип економічної системи; тип державного підприємства; його функціональна залежність від органів влади; структура контролю держави над належними їй активами.

Практична значимість. Отримані результати, будучи впровадженими в діяльність конкурентного відомства, забезпечать більш коректний ринковий аналіз передумов і практики конкуренції на окремих ринках і в економіці в цілому.

Ключові слова: підприємство державної форми власності, контроль, ринковий аналіз, стандарт ринкового аналізу, конкуренція

\section{Определение стандарта рыночного анализа в отраслях со значительной долей государственных предприятий}

\author{
Н.А. Мазараки, А. Г. Герасименко
}

Киевский национальный торгово-экономический университет, г. Киев, Украина, e-mail: n.mazaraki@knute.edu.ua

Цель. Определение критериев, детерминирующих выбор стандарта рыночного анализа в отраслях со значительной долей государственных предприятий.

Методика. Теоретико-методическим основанием исследования является компаративный анализ принципов классификации и опыта функционирования предприятий государственной формы собственности в разных странах мира, результатов их рыночного анализа в рамках неоклассического и институционального стандартов, на основании которых выделен набор критериев, детерминирующих предпосылки использования каждого из стандартов.

Результаты. В работе обоснована недопустимость повсеместного использования неоклассического подхода к рыночному анализу в отраслях со значительной долей государственных предприятий. Детерминирован набор критериев, которые определяют, в каких условиях следует использовать неоклассический, а в каких - институциональный стандарт рыночного анализа.

Научная новизна. Определены критерии, которые детерминируют выбор стандарта рыночного анализа в отраслях со значительной долей государственных предприятий, в числе которых: тип экономической системы; тип государственного предприятия; его функциональная зависимость от органов власти; структура контроля государства над принадлежащими ему активами.

Практическая значимость. Полученные результаты, будучи внедренными в деятельность конкурентного ведомства, обеспечат более корректный рыночный анализ предпосылок и практики конкуренции на отдельных рынках и в экономике в целом.

Ключевые слова: предприятие государственной формы собственности, контроль, рыночный анализ, стандарт рыночного анализа, конкуренция

Recommended for publication by S. V. Melnychenko, Doctor of Economic Sciences. The manuscript was submitted 17.04.20. 